\title{
Hubungan Peran Wanita dalam Pengambilan Keputusan dengan Penggunaan Kontrasepsi Modern pada Wanita Usia 15-49 Tahun di Indonesia (Analisis Data SDKI 2017)
}

\section{The Relationship between the Role of Women in Decision Making and the Use of Modern Contraceptives in Women Ages 15-49 in Indonesia (Data Analysis for the 2017 IDHS)}

\author{
Eni Setiyowati ${ }^{1}$, Sudarto Ronoatmodjo² \\ 1 Mahasiswa Pascasarjana Fakultas Kesehatan Masyarakat Universitas Indonesia \\ 2 Departemen Epidemiologi Fakultas Kesehatan Masyarakat Universitas \\ Indonesia \\ E-mail: eniswet1@gmail.com
}

Penyerahan: 22-01-2020, Perbaikan: 22-01-2021, Diterima:25-01-2021

\begin{abstract}
The high rate of population growth causes problems in various countries including in Indonesia. Control efforts are carried out by means of the Family Planning program. However, the Contraceptive Prevalence Rate (CPR) figure of $64 \%$ has not met the 2019 National Medium Term Development Plan (RPJMN) target of $66 \%$ and there is a tendency for the trend of modern family planning to decline. Various factors influence the selection of modern contraception, including the role of women in making decisions for family planning, this is related to the issue of gender inequality in the field of family planning and reproductive health where there is still an assumption that users of contraception are women's business. This study aims to determine the relationship between the role of women in decision making with the use of modern contraception. The design of this study was cross sectional using data from the 2017 Indonesian Health Demographic Survey (IHDS). The sample in this study was women aged 15-49 years who were registered in the 2017 IDHS data who met the inclusion criteria of 17,234. The analysis in this study uses cox regression. The results of multivariat analysis stated that there was a relationship between the role of women in decision making with the use of modern contraception with a $P R$ value of 1,13 (1,061-1,201). It was concluded that women who played a role in decision making increased risk by 1,128 times when compared to women who did not play a role in decision making using modern contraception. Increased knowledge and information for women who have influence in participating in decision-making related to health problems, especially those related to themselves.
\end{abstract}

\section{Keywords: modern contraception; The role of decision making}

\begin{abstract}
ABSTRAK
Tingginya laju pertumbuhan penduduk menimbulkan permasalahan diberbagai negara termasuk di Indonesia. Upaya pengendalian dillakukan dengan cara program Keluarga Berencana. Akan tetapi angka Contraceptive Prevalence Rate (CPR) sebesar 64\% belum memenuhi target Rencana Pembangunan Jangka Menengah Nasional (RPJMN) 2019 sebesar $66 \%$ dan adanya kecenderungan trend penggunaan KB modern yang cenderung menurun. Berbagai faktor berpengaruh dalam pemilihan kontrasepsi modern diantaranya peran wanita dalam pengambilan keputusan untuk ber $\mathrm{KB}$, hal ini terkait dengan isu ketidaksetaraan gender dalam bidang KB dan kesehatan reproduksi dimana masih ada anggapan bahwa pengguna kontrasepsi adalah urusan perempuan. Penelitian ini bertujuan untuk mengetahui besar hubungan antara peran wanita dalam
\end{abstract}


pengambilan keputusan dengan penggunaan kontrasepsi modern. Desain penelitian ini adalah cross sectional menggunakan data Survei Demografi Kesehatan Indonesia (SDKI) 2017. Sampel dalam penelitian ini adalah wanita usia 15-49 tahun yang terdaftar dalam data SDKI 2017 yang memenuhi kriteria inklusi sebesar 17.234. Analisis dalam penelitian ini menggunakan cox regression. Hasil analisis multivariat menyatakan ada hubungan antara peran wanita dalam pengambilan keputusan dengan penggunaan kontrasepsi modern dengan nilai Prevalence Ratio (PR) sebesar 1,13(1,061-1,201). Disimpulkan bahwa wanita yang berperan dalam pengambilan keputusan meningkatkan risiko sebesar 1,13 kali bila dibandingkan dengan wanita yang tidak berperan dalam pengambilan keputusan yang menggunakan kontrasepsi modern. Peningkatan pengetahuan dan informasi bagi wanita mempunyai pengaruh dalam berperan serta pada pengambilan suatu keputusan yang berkaitan dengan masalah kesehatan terutama yang berkaitan dengan dirinya sendiri.

\section{Kata kunci: kontrasepsi modern; Peran pengambilan keputusan}

\section{PENDAHULUAN}

\author{
Pesatnya
}

pertumbuhan

penduduk menimbulkan masalah bagi negara-negara di dunia, khususnya negara berkembang. Menurut data Kementrian Kesehatan perkiraan jumlah penduduk Indonesia yaitu 249 juta jiwa (Kementrian Kesehatan RI, 2014). Pertumbuhan akan terus meningkat dan diprediksi tahun 2050 penduduk Indonesia mencapai 400 juta jiwa dan akan menggeser posisi Amerika Serikat setelah China dan India (Siregar, 2016).

$$
63 \% \text { dari wanita di seluruh }
$$

dunia menggunakan beberapa bentuk kontrasepsi. Penggunaan kontrasepsi yang mencapai $70 \%$ berasal dari Eropa, Amerika Latin dan Karibia, serta Amerika Utara, sementara di bawah 25 \% di Afrika Tengah dan Barat (United Nations, 2017).Data World Health Organization (WHO) menunjukkan pengguna kontrasepsi di Asia naik sedikit dari $60,9 \%$ menjadi $61,8 \%$ (WHO, 2018). Di Indonesia Angka Contraceptive Prevalence Rate (CPR) pada tahun 2012 sebesar 57,9\% (Kementerian Kesehatan RI, 2013) dan berdasarkan hasil Survei Demografi Kesehatan Indonesia (SDKI) tahun 2017 meningkat menjadi 64\% (Kementrian Kesehatan RI, 2018) akan tetapi angka tersebut masih belum memenuhi target Rencana Pembangunan Jangka Menengah Nasonal (RPJMN) 2015-2019 sebesar $66 \%$ (Kementrian Perencanaan Pembangunan Nasional/Badan Perencanaan Pembangunan Nasional, 2014). Trend penggunaan alat kontrasepsi modern cenderung menurun dimana tahun 2017 sebesar $57 \%$ sedangkan tahun 2012 mencapai 58\%, dan penggunaan alat kontrasepsi tradisional (Kiswanto, 2015).

Penggunaan kontrasepsi dipengaruhi oleh beberapa faktor diantaranya faktor sosial dan ekonomi. Secara khusus, pengetahuan, keterjangkauan dan aksesibilitas kontrasepsi, komunikasi pasangan tentang kesuburan dan keluarga berencana, dan dukungan suami serta paparan media massa juga merupakan faktor yang mempengaruhi seorang wanita untuk menggunakan alat kontrasepsi (Poppov, 2015). Sedangkan menurut Lindh tahun 2011 selain faktor diatas faktor seksualitas, usia, paritas, kebijakan sosial, moral, keyakinan budaya dan agama juga menjadi faktor yang ikut menentukan sikap seseorang dalam menggunakan alat kontrasepsi (Capova, 2014).

Keberhasilan Program KB tidak terlepas dari partisipasi 
masyarakat.

Pemberdayaan

masyarakat di bidang kesehatan harus ditingkatkan sehingga masyarakat mampu untuk hidup secara berkualitas. Partisipasi wanita dalam memutuskan alat kontrasepsi apa yang akan digunakan maka akan memperjelas apa yang sebenarnya dikehendaki oleh wanita itu sendiri dan semakin banyak wanita yang terlibat dalam pengambilan keputusan akan semakin baik. Partisipasi dan pemberdayaan wanita merupakan salah satu langkah dalam mencapai keberhasilan program KB, yang tentu juga harus didukung oleh anggota keluarga yang lain. Partisipasi wanita dalam KB bukan semata-mata karena wanita merupakan suatu obyek dalam penggunaan alat kontrasepsi akan tetapi lebih kepada mendorong wanita untuk meningkatkan keberdayaannya dalam pengambilan keputusan baik untuk dirinya sendiri maupun keluarganya. Pemilihan jenis kontrasepsi atau keikutsertaan dalam program KB juga menjadi tanggung jawab suami dimana suami dapat memberikan dukungan berupa izin dalam penggunaan alat kontrasepsi atau suami yang menggunakan alat kontrasepsi sehingga tidak menimbulkan diskriminasi dan ketimpangan peran serta tanggung jawab dalam keluarga. Akan tetapi masalah isu ketidaksetaraan gender dalam bidang KB dan kesehatan reproduksi serta ada anggapan bahwa pengguna kontrasepsi adalah urusan perempuan masih merupakan salah satu faktor yang harus diselesaikan.

Semakin banyak wanita yang diberdayakan, semakin besar kemungkinan menggunakan kontrasepsi modern, melahirkan di fasilitas kesehatan dengan tenaga yang terlatih. Pemberdayaan wanita mengarah pada perubahan positif yang signifikan di banyak domain. Studi telah menemukan hubungan antara peningkatan pemberdayaan wanita dan penurunan mortalitas dan morbiditas (Yaya et al., 2018). Talapere Usha Kiran dkk (2015) dalam penelitiannya menyatakan bahwa wanita yang berperan dalam pengambilan keputusan dan menggunakan kontrasepsi sebesar $54,6 \%$ dan wanita yang tidak berperan dalam pengambilan keputusan dan menggunakan kontrasepsi sebesar 44\% (Talapere Usha Kiran, Rajshree Dayanand Katke, Priyadarshini Mane, Priyadarshini Mane, 2019).

Beberapa hasil penelitian baik dari dalam maupun luar negeri, seperti yang dilakukan di Indonesia mengenai pengambilan keputusan antara lain dilakukan oleh Dwi Astuti (2015) menunjukkan bahwa ada hubungan yang signifikan antara peran wanita dalam pengambilan keputusan dengan penggunaan kontrasepsi dengan nilai $p$ value 0,004 (Astuti \& Ilyas, 2015). Tien Ihsani (2018) dalam penelitiannya tentang peran wanita dalam pengambilan keputusan menunjukkan bahwa peran wanita mempunyai hubungan yang signifikan terhadap penggunaan Metode Kontrasepsi Jangka Panjang (MKJP) dengan nilai OR 3,3 (Ihsani, 2018).

Salah satu peran penting dalam penggunaan kontrasepsi adalah peran wanita dalam pengambilan keputusan dengan penggunaan metode kontrasepsi modern. Peran pemberdayaan wanita dalam memutuskan alat kontrasepsi apa yang akan digunakan yang merupakan salah satu hak wanita dalam menjaga kesehatan dirinya. Oleh karena itu penulis tertarik untuk mengetahui 
tentang hubungan peran wanita dalam pengambilan keputusan dengan penggunaan metode kontrasepsi modern pada wanita di Indonesia.

Tujuan dalam penelitian ini adalah untuk mengetahui hubungan antara peran wanita dalam pengambilan keputusan dengan penggunaan kontrasepsi modern pada wanita usia 115-49 tahun di Indonesia (analisis data SDKI 2017).

\section{METODO}

Desain Penelitian ini cross sectional dengan menggunakan data sekunder yang bersumber dari hasil Survei Demografi Kesehatan Indonesia (SDKI) tahun 2017 yang dilakukan di 34 provinsi. Dimana dalam SDKI 2017 mencakup 1.970 blok sensus yang meliputi daerah perkotaan dan perdesaan, dengan Kerangka sampel SDKI 2017 menggunakan Master Sampel Blok Sensus dari hasil Sensus Penduduk 2010 (SP2010). Seluruh individu wanita yang ikut serta dalam wawancara Survei SDKI tahun 2017 yang berjumlah 49.627 orang yang bersedia diwawancarai atau menjadi responden pada SDKI tahun 2017.

Berdasarkan

perhitungan

besar dengan menggunakan uji perbedaan dua proporsi diperoleh sampel minimal sebanyak 382 responden. Sedangkan kriteria inklusi pada sampel penelitian ini yaitu wanita yang berumur 15-49 tahun pengguna kontrasepsi yang terdapat dalam data SDKI tahun 2017 sudah menikah serta mempunyai data yang lengkap berjumlah 17234. Maka semua sampel yang eligble sebanyak 17.234 diikutsertakan dalam analisis. Semakin besar jumlah sampel diharapkan akan semakin mewakili populasi yang diteliti, sehingga kesalahan dalam pemilihan sampel dapat dikurangi dan interval kepercayaan akan semakin baik.

Variabel yang akan diteliti adalah penggunaan kontrasepsi modern sebagai variabel dependen dengan kelompok pembanding wanita yang menggunakan kontrasepsi tradisional dan peran wanita dalam pengambilan keputusan adalah variabel independennya, adapun variabel kovariatnya adalah umur, pekerjaan, pendidikan,jumlah anak, paparan media massa, dukungan suami dan pengetahuan tentang $\mathrm{KB}$. Variabel dependen dalam penelitian ini adalah penggunaan kontrasepsi modern terdiri dari pil ,suntik, IUD, implant/susuk, MOP, MOW, kondom, pil kontrasepsi darurat, MAL dan diafragma yang diperoleh dari hasil wawancara berdasarkan kuesioner SDKI-WUS dengan pertanyaan "Alat/cara KB apa yang ibu/saudari gunakan?".

\section{Sedangkan}

variabel independenya adalah peran wanita dalam pengambilan keputusan yang diperoleh dari hasil wawancara berdasarkan kuesinoer SDKI dengan pertanyaan "Apakah memakai alat/cara KB merupakan keputusan ibu/saudari,keputusan

suami/pasangan ibu/saudari atau keputusan bersama?" dan variabel lain seperti umur diperoleh dari kuesioner SDKI dengan pertanyaan "Berapa umur ibu/saudari pada ulang tahun terakhir?", pekerjaan dengan pertanyaan"Apa jenis pekerjaan ibu/saudari?", pendidikan dengan pertanyaan"Apa Jenjang pendidikan tertinggi yang pernah/sedang ibu/saudari duduki?", jumlah anak dengan pertanyaan "Berapa jumlah anak ibu/saudari?", paparan media massa dengan pertanyaan " Dalam 6 bulan terakhir apakah ibu/saudari pernah mendengar tentang $\mathrm{KB}$ di radio, 
melihat tayangan tentang $\mathrm{KB}$ di televisi,membaca tentang $\mathrm{KB}$ di Koran/majalah, membaca tentang KB di poster/pamphlet/leaflet, membaca tentang $\mathrm{KB}$ melalui biilboard/spanduk/umbul-umbul,

membaca tentang $\mathrm{KB}$ melalui internet", dukungan suami dengan pertanyaan " menurut ibu/saudari apakah suami/pasangan ibu/saudari setuju atau tidak sutuju jika suatu pasangan menggunakan alat/cara KB untuk mencegah kehamilan?", dan pengetahuan tentang dengan pertanyaan "apakah ibu/saudari pernah mendengar alat/cara KB", dengan 12 pertanyaan apabila score $>76 \%$ dikatakan baik dan dibawah $<75 \%$ dikatakan kurang ).

Analisis multivariat dalam penelitian ini menggunakan cox regression. Cox merupakan alternative yang tepat jika hendak menghasilkan nilai PR pada studi cross sectional dibandingkan uji statistic yang umum digunakan yaitu Logistic Regression. Ujii Logistic Regression menghasilkan nilai Odss Ratio (OR) dimana formula dan interpretasi Nilai OR berbeda dengan nilai PR. PR merupakan perbandingan prevalensi efek (out come) pada kelompok terpajan dan tidak terpajan, sedangkan OR merupakan perbandingan odds terpajan pada kasus dan control. Nilai PR diperlukan untuk penelitian disesuaikan dengan nilai Hazard Ratio (HR) yang dihasilkan dari uji Cox. Dikatakan sesuai karena pada dasarnya HR adalah perbandingan efek (out come) pada kelompok yang terpajan dan tidak terpajan (Kleinbaum, David G., Klein, 2005). Berikutnya terlebih dahulu dilakukan seleksi bivariat dengan penentuan variabel potensial berdasarkan nilai $p$ value < 0,25 yang akan masuk kedalam model untuk mendapatkan model gold standar. Tahap selanjutnya yaitu dengan melakukan uji interaksi untuk melihat apakah terdapat variabel yang berinteraksi terhadap hubungan peran pengambilan keputusan dengan penggunaan kontrasepi dengan melihat nilai $p$ value variabel yang diinteraksikan bila nilai $p<0,05$ maka variabel tersebut merupakan variabel interaksi dan tetap masuk kedalam model. Selanjutnya dilakukan penilaian confounding dengan cara melihat perubahan nila PR bila perubahan PR $>10 \%$ maka variabel tersebut merupakan confounding dan tetap masuk kedalam model sehingga diperoleh model akhir. Penggunaan pemodelan faktor risiko digunakan untuk melakukan estimasi hubungan peran wanita dalam pengambilan keputusan dengan penggunaan kontrasepsi modern dengan mengontrol variabel-variabel kovariat secara valid (Hastono, 2016).

\section{HASIL}

Gambaran populasi responden berdasarkan data SDKI tahun 2107 disajikan pada tabel 1. Dari 17234 responden dengan pengguna kontrasepsi modern sebesar 14940 $(86,7 \%)$, sedangkan wanita yang berperan dalam pengambilan keputusan sebesar 15845(91,9\%). Pada variabel kovariatnya dapat dilihat bahwa 45,5\% merupakan responden yang berumur $<35$ tahun, pada tingkat pendidikan tinggi sebesar $69,4 \%$, responden dengan jumlah anak $>2$ sebesar $42,9 \%, 61,7 \%$ wanita bekerja, yang mendapat dukungan suami hanya 1,4 dan yang terpapar media massa sebesar $59 \%$. 
Tabel 1. Distribusi Frekuensi Responden

\begin{tabular}{|c|c|c|c|}
\hline Variabel & Kategori & $\begin{array}{c}\text { Jumla } \\
\text { h }\end{array}$ & $\begin{array}{c}\text { Presentase } \\
(\%)\end{array}$ \\
\hline \multirow{2}{*}{ Penggunaan Kontrasepsi } & Modern & 14940 & 86,7 \\
\hline & Tradisional & 2294 & 13,3 \\
\hline \multirow{2}{*}{$\begin{array}{lll}\begin{array}{l}\text { Perandalam } \\
\text { Keputusan }\end{array} & \text { dalam } & \text { pengambilan } \\
\end{array}$} & Berperan & 15845 & 91,9 \\
\hline & Tidak berperan & 1389 & 8,1 \\
\hline \multirow[t]{2}{*}{ Umur } & $<35$ tahun & 7849 & 45,5 \\
\hline & $>=35$ tahun & 9385 & 54,5 \\
\hline \multirow[t]{2}{*}{ Pendidikan } & Tinggi & 11969 & 69,4 \\
\hline & Rendah & 5265 & 30,6 \\
\hline \multirow[t]{2}{*}{ Jumlah anak } & $>2$ & 7394 & 42.9 \\
\hline & $<=2$ & 9840 & 57.1 \\
\hline \multirow{2}{*}{ Pengetahuan tentang alat kontrasepsi } & Baik & 3520 & 20,4 \\
\hline & Kurang & 13714 & 79,6 \\
\hline \multirow[t]{2}{*}{ Pekerjaan } & Bekerja & 10637 & 61.7 \\
\hline & Tidak bekerja & 6597 & 38.3 \\
\hline \multirow[t]{2}{*}{ Dukungan suami } & Mendukung & 239 & 1.4 \\
\hline & $\begin{array}{l}\text { Tidak } \\
\text { mendukung }\end{array}$ & 16995 & 98.6 \\
\hline \multirow[t]{2}{*}{ Paparan Media massa } & Terpapar & 10165 & 59 \\
\hline & Tidak terpapar & 7069 & 41 \\
\hline
\end{tabular}

Berdasarkan hasil penelitian yang tertera dalam tabel 2 menunjukkan bahwa wanita yang berperan dalam pengambilan keputusan dan menggunakan kontrasepsi modern sebesar 13863 $(87,5 \%)$ sedangkan wanita yang tidak berperan dalam pengambilan keputusan yang menggunakan kotrasepsi modern sebesar 77,5\%. Hasil Uji Chi-Square diperoleh nilai $p$ 0,0001, maka dapat disimpulkan bahwa ada perbedaan proporsi penggunaan kontrasepsi modern pada wanita yang berperan dalam pengambilan keputusan dengan yang tidak berperan dalam pengambilan keputusan. Dari hasil analisis diperoleh nilai $\mathrm{PR}=1,13 \quad(95 \% \mathrm{CI}$ : 1,061-1,201) artinya wanita yang berperan dalam pengambilan keputusan mempunyai peluang lebih tinggi untuk menggunakan kontrasepsi modern sebesar 1,13 kali bila dibandingkan dengan wanita yang tidak berperan dalam pengambilan keputusan untuk menggunakan kontrasepsi modern. Wanita berumur < 35 tahun yang menggunakan KB modern sebesar $89 \%$ sedangkan pada wanita umur $>35$ tahun sebesar $84,8 \%$ yang menggunakan KB modern. Wanita dengan pendidikan tinggi yang menggunakan $\mathrm{KB}$ modern sebesar $84,8 \%$ sedangkan dengan pendidikan rendah sebesar 91,1\%. Tidak ada perbedaan proporsi antara wanita dengan jumlah anak $<2$ dan $>$ 2. Pada wanita dengan pengetahuan tentang $\mathrm{KB}$ yang baik yang menggunakan $\mathrm{KB}$ modern sebesar $80,6 \%$ dan dengan pengetahuan yang kurang sebesar $88,2 \%$. Tidak ada perbedaan proporsi pada wanita yang bekerja dan yang tidak bekerja yang menggunakan KB modern. Wanita yang mendapat dukungan suami dan menggunakan KB modern sebesar $91,6 \%$ dan yang tidak mendapat dukungan sebesar 86,6 dan menggunakan KB modern serta tidak terdapat perbedaan proporsi antara 
wanita yang terpapar dan wanita yang tidak terpapar media massa.

Berdasarkan analisis bivariat beberapa variabel memenuhi syarat masuk kedalam analisis multivariat ( nilai $\mathrm{p}<0,25$ ) yaitu umur, pendidikan, pengetahuan tentang alat kontrasepsi, pekerjaan dan media massa, akan tetapi secara substansi semua variabel dimasukkan ke dalam analisis (tabel 2).

Tabel 2. Hubungan variabel independen utama dan kovariat terhadap penggunaan kontrasepsi modern

\begin{tabular}{|c|c|c|c|c|c|c|c|}
\hline \multirow[t]{3}{*}{ Variabel } & \multirow[t]{3}{*}{ 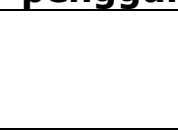 } & \multicolumn{4}{|c|}{ Penggunaan Kontrasepsi } & \multirow[t]{3}{*}{ p value } & \multirow{3}{*}{$\begin{array}{c}\text { PR } \\
95 \% \text { CI }\end{array}$} \\
\hline & & \multicolumn{2}{|c|}{ Modern } & \multicolumn{2}{|c|}{ Tradisional } & & \\
\hline & & $\mathbf{N}$ & $\%$ & $\mathbf{N}$ & $\%$ & & \\
\hline $\begin{array}{ll}\text { Peran } & \text { dalam }\end{array}$ & Ya & 13863 & 87,5 & 1982 & 12,5 & & 1,13 \\
\hline Pengambilan keputusan & Tidak & 1077 & 77,5 & 312 & 22,5 & 0,0001 & $(1,06-1,20)$ \\
\hline \multirow[t]{2}{*}{ Umur } & $<35$ th & 6984 & 89 & 865 & 11 & 0,003 & 1,050 \\
\hline & $>=35$ th & 7956 & 84,8 & 1429 & 15,2 & & $(1,016-1,084)$ \\
\hline \multirow[t]{2}{*}{ Pendidikan } & Tinggi & 10145 & 84,8 & 1824 & 15,2 & 0,000 & 0,93 \\
\hline & Rendah & 4795 & 91,1 & 470 & 8,9 & & $(0,89-0,96)$ \\
\hline \multirow[t]{2}{*}{ Jumlah anak } & $>2$ & 6373 & 86,2 & 1022 & 13,8 & 0,532 & 0,99 \\
\hline & $<=2$ & 8568 & 87,1 & 1272 & 12,9 & & $(0,95-1,02)$ \\
\hline \multirow{2}{*}{$\begin{array}{l}\text { Pengetahuan tentang } \\
\text { alat kontrasepsi }\end{array}$} & Baik & 2838 & 80,6 & 682 & 19,4 & 0,0001 & 0,91 \\
\hline & Kurang & 12102 & 88,2 & 1612 & 11,8 & & $(0,87-0,95)$ \\
\hline \multirow[t]{2}{*}{ Pekerjaan } & Bekerja & 9087 & 85,5 & 1540 & 14,5 & 0,037 & 0,96 \\
\hline & $\begin{array}{l}\text { Tidak } \\
\text { Bekerja }\end{array}$ & 5843 & 88,6 & 754 & 11,4 & & $(0,93-0,99)$ \\
\hline \multirow[t]{2}{*}{ Dukungan suami } & Didukung & 219 & 91,6 & 20 & 8,4 & 0,409 & 1,05 \\
\hline & $\begin{array}{l}\text { Tidak } \\
\text { didukung }\end{array}$ & 14721 & 86,6 & 2274 & 13,4 & & $(0,926-1,20)$ \\
\hline \multirow[t]{2}{*}{ Paparan media massa } & Terpapar & 8722 & 85,8 & 1443 & 14,2 & 0,135 & 1,025 \\
\hline & $\begin{array}{l}\text { Tidak } \\
\text { terpapar }\end{array}$ & 6218 & 88 & 851 & 12 & & $(0,992-1,059)$ \\
\hline
\end{tabular}

Dalam tahap analisis multivariat dilakukan uji interaksi untuk melihat variabel-variabel yang berinteraksi terhadap hubungan peran pengambilan keputusan dengan penggunan kontrasepi dengan melihat nilai $\mathrm{p}$ value pada varibel yang diinteraksikan bila nilai $p<0,05$ maka variabel tersebut merupakan variabel interaksi dan tetap masuk kedalam model.

Selanjutnya Uji confounding yang dilakukan secara bertahap dengan mengeluarkan variabel yang nilai $p$ value nya paling besar kemudian dilihat perubahan pada nlai PR variabel independen utamanya yaitu peran wanita dalam pengambilan keputusan pada model awal terhadap nilai PR pada model setelah mengeluarkan variabel kovariat satu persatu. Bila perubahan $<10 \%$ variabel tersebut bukan merupakan confounding dan akan dikeluarkan dari model dan bila PR > $10 \%$ maka variabel tersebut dianggap sebagai confounding dan tetap masuk ke dalam model. Hasil analisis uji interaksi dalam penelitian ini diperoleh hasil bahwa tidak ada satu variabel pun yang merupakan variabel interaksi dan pada analisis uji confounding menunjukkan bahwa tidak terdapat variabel confounding. Sehingga hasil analisis multivariat pada akhir pemodelan di peroleh nilai PR peran wanita dalam pengambilan keputusan $=1,13$ ( CI: $95 \%$ 1,061-1,201) yang artinya wanita yang berperan dalam pengambilan keputusan memiliki peluang sebesar 1,13 kali untuk menggunakan kontrasepsi modern bila dibandingkan dengan wanita yang tidak berperan dalam pengambilan keputusan untuk 
menggunakan kontrasepsi modern ( tabel 3).

Tabel 3 Model Akhir Analisis Multivariat

\begin{tabular}{llll}
\hline Variabel & P value & PR & CI 95\% \\
\hline Peran dalam pengambilan keputusan & 0,0001 & 1,13 & $1,061-1,201$ \\
\hline
\end{tabular}

\section{PEMBAHASAN}

Hasil

penelitian ini

menunjukkan bahwa terdapat hubungan yang signifikan antara peran wanita dalam pengambilan keputusan dengan penggunaan kontrasepsi dimana pengambilan keputusan dilakukan wanita dan bersama suami dengan nilai $\mathrm{PR}=$ 1,13 ( $95 \%$ CI : 1,061-1,201) artinya wanita yang berperan dalam pengambilan keputusan mempunyai peluang sebesar 1,13 kali untuk menggunakan kontrasepsi modern bila dibandingkan dengan wanita yang tidak berperan dalam pengambilan keputusan untuk menggunakan kontrasepsi modern.

Hal ini menunjukkan bahwa dimensi pemberdayaan wanita dalam pengambilan keputusan terhadap pemilihan alat kontrasepsi memiliki hubungan secara positif dengan penggunaan kontrasepsi modern. Wanita yang berperan dalam pengambilan keputusan memiliki kecenderungan menggunakan kontrasepsi modern sedangkan wanita yang tidak berperan dalam pengambilan keputusan lebih memilih menggunakan alat kontrasepsi tradisional.

$$
\text { Dalam penelitian ini }
$$

pemberdayaan wanita dalam pengambilan keputusan terhadap pemilihan alat kontrasepsi memiliki hubungan positif dengan penggunaan kontrasepsi modern. Keterlibatan wanita dalam proses pengambilan keputusan relatif tertinggal dibandingkan laki-laki hal ini berpengaruh terhadap hasil keputusan yang menyangkut kepentingan wanita dalam semua aspek kehidupan. Berbagai macam faktor seperti budaya dimana nilainilai sosial budaya patriarki ini secara langsung maupun tidak langsung dapat menempatkan lakilaki dan wanita pada kedudukan dan peran yang berbeda dan tidak setara serta ketidaktepatan dalam pemahaman seringkali menyudutkan kedudukan dan peranan wanita di dalam keluarga serta masyarakat sehingga dapat menjadi faktor penghambat untuk pengambilan keputusan, disamping kodrat sebagai wanita yang sangat menentukan derajat kesehatan dirinya (KemenPPA \& BPS, 2018).

Selain faktor budaya, agama terdapat faktor lain yag dapat mempengarui peran wanita dalam pengambilan keputusan yaitu pengetahuan wanita atau informasi yang diperoleh wanita mengenai kontrasepsi, tingkat pendidikan, lingkungan sosial dan juga keadaan ekonomi dalam rumah tangga. Dalam menentukan alat kontrasepsi yang akan digunakan seseorang membutuhkan pengetahuan dan informasi tentang alat/cara KB secara menyeluruh. Dengan pengetahuan yang baik seorang wanita dapat memilih alat kontrasepsi secara rasional yaitu yang efektif dan sesuai dengan dirinya dan tentunya dengan pengetahuan yang baik maka semakin meningkatkan kepercayaan diri serta keberdayaan wanita dalam pengambilan keputusan mengenai kesehatan dirinya sendiri. 
Dalam penyebaran informasi tentang kontrasepsi tentu peran sumberdaya berkaitan dengan kompentensi petugas dalam tekhnis pelayanan dan dalam memberikan konseling sangat besar pengaruhnya. Melalui konseling yang baik maka petugas telah membantu wanita dalam memilih dan memutuskan jenis kontrasepsi apa yang akan dipilih dan digunakan. Hal ini sesuai dengan penelitian Bari Saifudin tahun 2003 yang menyatakan bahwa konseling yang berkualitas akan memberikan kepuasan dan membantu keberhasilan program KB (Handayani et al., n.d.).

Dan tingkat pendidikan juga mempengaruhi wawasan seorang wanita dimana semakin tinggi pendidikan maka seorang wanita akan semakin mudah dalam menerima informasi yang disampaikan baik oleh petugas kesehatan ataupun informasiinformasi dari media massa. Dan dengan pendidikan yang tinggi wanita lebih berdaya dan mampu dalam pengambilan keputusan (Lambelanova \& Ramadhan, 2016). Akan tetapi dalam penelitian ini tingkat pendidikan wanita yang rendah lebih besar memilih kontrasepsi modern dibandingkan dengan pendidikan yang tinggi. Hal ini dimungkinan karena peran petugas kesehatan terutama bidan di desa dimana peran bidan mampu mempengaruhi wanita dalam pengambilan keputusan dalam pemilihan alat kontrasepsi.

Hasil penelitian ini sejalan dengan beberapa penelitian baik dari dalam maupun luar negeri, seperti yang dilakukan di Indonesia mengenai pengambilan keputusan antara lain dilakukan oleh Dwi astuti hasil nya menunjukkan bahwa ada hubungan yang signifikan antara peran wanita dalam pengambilan keputusan dengan penggunaan kontrasepsi dengan nilai $p$ value 0,004 (Astuti \& Ilyas, 2015). Tien Ihsani ( 2018 ) dalam penelitiannya tentang peran wanita dalam pengambilan keputusan menunjukkan bahwa peran wanita mempunyai hubungan yang signifikan terhadap penggunaan kontrasepsi MKJP dengan nilai OR 3,3 (Ihsani, 2018).

Sedangkan penelitian yang dilakukan oleh Setiadi ( 2015 ) dalam penelitiannya menunjukkan hasil bahwa peran wanita dalam pengambilan keputusan berhubungan secara signifikan terhadap penggunaan alat kontrasepsi dengan nilai OR 1,706 (Iswanto, 2015). Ema ( 2015 ) dalam penelitiannya yang dilakukan di Lombok Timur dengan variabel peran wanita dalam pengambilan keputusan menunjukkan bahwa peran wanita dalam pengambilan keputusan mempunyai hubungan yang signifikan dengan penggunaan kontrasepsi dengan nila OR sebesar 1,64 (Sholihah, 2015). Penelitian yang dilakukan oleh Nani Mulyani (2003) menunjukkan bahwa peran wanita dalam pengambilan keputusan berhubungan dengan penggunaan alat kontrasepsi secara signifikan dengan nilai OR 1,24 (Mulyani, 2003).

Sedangkan dalam beberapa penelitian di luar negeri dengan menggunakan variabel peran wanita dalam pengambilan keputusan yang berbeda menunjukkan bahwa terdapat hubungan yang signifikan dengan penggunaan kontrasepsi modern. Seperti yang dilakukan di empat Negara yaitu Ghana, Kenya, Madagaskar dan Zambia hasil analisis menunjukkan bahwa ada hubungan positif antara pemberdayaan wanita dalam pengambilan keputusan dengan 
penggunaan kontrasepsi di mana wanita yang lebih berdaya lebih cenderung menggunakan kontrasepsi dengan metode yang lebih efektif ( modern ) daripada wanita yang tidak (Larsson \& Stanfors, 2014).

Penelitian yang dilakukan di Ethiopia tahun 2011 peran wanita dalam pengambilan keputusan secara signifikan terkait dengan penggunaan kontrasepsi dengan nilai OR 1,26 ( 95\% CI 1.19,1.33 ). (Tadesse et al., 2015).

Aparajita Dasgupta dkk di India ( 2015 ) dalam penelitiannya melaporkan bahwa kekuatan wanita dalam pengambilan keputusan dengan penggunaan kontrasepsi menghasilkan nilai OR 1.11 dengan 95\% CI (1.02-1.22) secara signifikan terkait dengan penggunaan kontrasepsi, (Dasgupta et al., 2016).

Penelitian yang dilakukan oleh Mai Do1 and Rieza Soelaeman ( 2017 ) di 3 negara di asia yaitu Kamboja, Bangladesh dan Indonesia mengenai pemberdayaan wanita dan penggunaan kontrasepsi modern. Di Negara Kamboja pengambilan keputusan ekonomi rumah tangga adalah satu-satunya dimensi pemberdayaan yang dikaitkan dengan penggunaan kontrasepsi modern. Pada wanita yang berperan dalam pengambilan keputusan lebih memilih metode jangka panjang dibandingkan dengan wanita yang tidak berperan dalam pengambilan keputusan.

Sedangkan Di Bangladesh partisipasi wanita dalam pengambilan keputusan memberikan efek positif terhadap peningkatan penggunaan kontrasepsi modern dengan penggunaan kontrasepsi modern dengan nilai RR 1,13 ( $p$ $<0,01)$.

Terdapat keterbatasan dalam penelitian ini diantaranya desain penelitian yang digunakan adalah cross sectional sehingga sulit untuk menjelaskan hubungan sebab akibat antara variabel independent dan variabel dependent karena pengambilan data faktor risiko dan efek dilakukan pada saat bersamaan sehingga sulit menjelaskan hubungan sebab akibat.

Bias informasi dapat terjadi bila responden tidak memberikan ketepatan informasi yang sesuai dengan keadaan sesuai dengan kondisinya. Akan tetapi untuk mencegah adanya bias informasi pada survey demografi kesehatan Indonesia menggunakan kuesioner yang terstruktur dan bagi petugas lapangan atau pewawancara diberikan pelatihan terlebih dahulu untuk menyamakan persepsi terhadap konsep dan definisi operasional variabel-variabel yang ditanyakan.

Dalam proses pemilihan telah dilakukan pembatasan yaitu sampel adalah wanita dengan usia 15-49 tahun, menikah dan sebagai pengguna kontrasepsi serta wanita yang tidak menikah, hamil dan sudah menopause dikeluarkan dalam pemilihan sampel. Hal ini dilakukan untuk mendapatkan sampel dengan karakteristik yang sama dalam mencegah terjadinya bias seleksi. Untuk menambah presisi, peneliti mengikutksertakan semua sampel eligble ke dalam penelitian ini yaitu sebanyak 17234 sampel. Semakin besar jumlah sampel, maka akan semakin mewakili populasi yang diteliti, sehingga kesalahan dalam pemilihan sampel dapat dikurangi, dan interval kepercayaan akan semakin presisi. Dari hasil penghitungan kembali power of study diperoleh power sebesar 99,9\%. Berdasarkan hasil yang diperoleh nilai confidence interval mempunyai rentang yang sempit dan 
power of study dalam penelitian ini cukup baik sehingga dapat disimpulkan bahwa kemungkinan terjadi random error dalam penelitian ini tidak begitu besar. Validitas eksternal dalam penelitian ini generalisasi hanya dilakukan pada populasi yang eligble.

Potensial terjadinya residual confounding dikarenakan terbatasnya ketersediaan data sehingga tidak semua faktor risiko di teliti seperti agama, budaya, ekonomi, peran petugas, peran tokoh agama dan peran program KB di era JKN.

\section{KESIMPULAN}

Prevalensi wanita usia 15-49 tahun yang menggunakan KB modern sebesar $86,7 \%$ dan yang menggunakan berperan dalam pengambilan keputusan sebesar $13,3 \%$. Penelitian ini menunjukkan hubungan yang bermakna antara peran wanita dalam pengambilan keputusan dengan penggunaan kontrasepsi modern. Wanita yang berperan dalam pengambilan keputusan memiliki peluang 1,13 (95\% CI: 1,076-1,149) kali bila dibandingkan wanita yang tidak berperan dalam pengambilan keputusan untuk menggunakan kontrasepsi modern.

\section{SARAN}

Untuk meningkatkan peran wanita diantaranya dengan melibatkan wanita dalam organisasi kemasyarakatan serta meningkatkan pendidikan yaitu dengan mengikutsertakan dalam program sekolah gratis bagi wanita yang putus sekolah, melibatkan wanita secara aktif dalam kegiatan ekonomi dan politik dan mengikutsertakan wanita dalam pendidikan keuangan keluarga, pendidikan ekonomi sesuai dengan potensi didaerahnya serta

\begin{tabular}{llr} 
pemerintah & juga & harus \\
melaksanakan & \multicolumn{2}{c}{ pembangunan } \\
berorientasi & pada peningkatan \\
partisipasi & angkatan & kerja \\
perempuan & dengan & prinsip \\
pemberdayaan dan & kesetaraan \\
gender misalnya ada regulasi \\
tentang keterwakilan perempuan \\
dalam suatu perusahaan.
\end{tabular}

\section{DAFTAR PUSTAKA}

Astuti, D., \& Ilyas, H. (2015). Faktor-faktor yang berhubungan pemilihan alat kontrasepsi suntik. Jurnal Artikel, XI(2), 233-243.

Capova, A. (2014). Factors influencing contraceptive choice: study focused on Czech men. 3(4), 880-886. https://doi.org/10.5455/23201770. ijrcog20141202

Dasgupta, A., Bandyopadhyay, K., Bandyopadhyay, L., Paul, B., \& Banerjee, S. (2016). Does Women Empowerment Predict Contraceptive Use? A Study in a Rural Area of Hooghly District, West Bengal. 28(03).

Handayani, L., Hariastuti, I., \& Latifah, C. (n.d.). Peningkatan informasi tentang $K B$ : hak kesehatan reproduksi yang perlu diperhatikan oleh program pelayanan keluarga berencana ( Enhance the Information of Family Planning: Reproductive Health Right that Should be Paid Attention by Family Planning Program. 289-297.

Hastono, S. P. (2016). Analisa Data Pada Bidang Kesehatan (1st ed.). PT Raja Grafindo Persada.

Ihsani, T. (2018). Peran pengambil keputusan terhadap penggunaan metode kontrasepsi jangka panjang ( MKJP) di Indonesia ( Analisis data sekunder SRPJMN 2017 ).

Iswanto, L. (2015). Pengambilan keputusan penggunaan alat 
kontrasepsi istri dalam keluarga. 23.

KemenPPA, \& BPS. (2018).

Pembangunan manusia berbasis gender.

Kementerian Kesehatan RI. (2013).

Situasi keluarga berencana di

Indonesia.

Kementrian Kesehatan RI. (2014).

infodatin-harganas.pdf.

Kementrian Kesehatan RI. (2018).

Survei Demografi dan Kesehatan Indonesia 2017.

Kementrian Perencanaan

Pembangunan Nasional/Badan

Perencanaan Pembangunan

Nasional. (2014). Peraturan

Presiden Republik Indonesia

Nomor 2 tahun 2015 tentang

Rencana Pembangunan Jangka

Menengah Nasional ( RPJMN )

2015-2019. 2015-2019.

https://doi.org/10.1017/CB09781

107415324.004

Kiswanto, E. (2015). the Dynamics of the Use of Contraceptives in

Ever-Married Women in

Indonesia : Data Analysis Ifls

1997,2000 and 2007. 23, 17-

37.

Kleinbaum, David G., Klein, M.

(2005). Survival Analisis, ASelf-

Learning Text (Second Edi).

Lambelanova, R., \& Ramadhan, M.

B. (2016). Peran Bada

Pemberdayaan Perempuan dan

Keluarga Berencana ( $B P P K B$ )

dalam Melaksanakan Program

Keluarga berencana Di Kabupaten

Tanah Laut Provinsi Kalimantan

Selatan. 9(1), 71-94.

Larsson, C., \& Stanfors, M. (2014).

Women's Education,

Empowerment, and

Contraceptive Use in $s$ ub-

Saharan Africa : Findings from

Recent Demographic and Health

Surveys. 28(2), 1022-1034.

Mulyani, N. (2003). Hubungan

Pengambilan Keputusan Untuk
Mmemilih Alat dengan Lama

Pakai Kontrasepsi Suntik (

Analisis data SDKI tahun 1997 ).

Poppov. (2015). Social and Economic

Factors Influence Contrasepstive

Use. October.

https://doi.org/10.1186/1472-

6874-11-46.2

Sholihah, E. M. (2015). hubungan

pemberdayaan perempuan

dengan penggunaan kontrasepsi

di Provinsi Nusa Tengga barat

tahun 2013.

Siregar, A. (2016). Kebijakan

Program Kependudukan,

Keluarga Berencana, dan

Pembangunan Keluarga. April.

Tadesse, M., Teklie, H., Yazew, G., \& Gebreselassie, T. (2015).

Women's Empowerment as a

Determinant of contrasceptive

Use in Ethiopia.

Talapere Usha Kiran, Rajshree

Dayanand Katke, Priyadarshini

Mane, Priyadarshini Mane, P. G.

P. (2019). How empowered are women to choose contraception ? 5(10), 2019-2025.

https://doi.org/10.5455/ijmsph.2 016.11022016404

United Nations. (2017). World Family Planning.

WHO. (2018). Family

planning/Contraception.

https://www.who.int/newsroom/fact-sheets/detail/familyplanning-contraception

Yaya, S., Uthman, O. A.,

Ekholuenetale, M., \& Bishwajit, G. (2018). Women empowerment as an enabling factor of contraceptive use in sub-Saharan Africa : a multilevel analysis of cross- sectional surveys of 32 countries. 1-12. 